\title{
The duration of the active phase on surge-type glaciers: contrasts between Svalbard and other regions
}

\author{
Julian A. Dowdeswell, GoRdon S. Hamilton, \\ Scott Polar Research Institute, University of Cambridge, Cambridge CB2 1ER, England \\ Jon Ove Hagen \\ Norsk Polarinstitutt, Postboks 158, 1330 Oslo Lufthavn, Norway
}

\begin{abstract}
Many glaciers in Svalbard and in other glacierized areas of the world are known to surge. However, the time series of observations required to assess the duration of fast motion is very restricted. Data on active-phase duration in Svalbard come from aerial photographs, satellite imagery, field surveys and airborne reconnaissance. Evidence on surge duration is available for eight Svalbard ice masses varying from 3 to $1250 \mathrm{~km}^{2}$. Worldwide, active-phase duration is recorded for less than 50 glaciers. Few observations are available on high polar ice masses. The duration of the active phase is significantly longer for Svalbard glaciers than for surgetype glaciers in other areas from which data are available. In Svalbard, the active phase may last from 3 to 10 years. By contrast, a surge duration of $1-2$ years is more typical of ice masses in northwest North America, Iceland and the Pamirs. Ice velocities during the protracted active phase on Svalbard glaciers are considerably lower than those for many surge-type glaciers in these other regions. Mass is transferred down-glacier more slowly but over a considerably longer period. Svalbard surge-type glaciers do not exhibit the very abrupt termination of the active phase, over periods of a few days, observed for several Alaskan glaciers. The duration of the active phase in Svalbard is not dependent on parameters related to glacier size. The quiescent phase is also relatively long (50-500 years) for Svalbard ice masses. Detailed field monitoring of changing basal conditions through the surge cycle is required from surge-type glaciers in Svalbard in order to explain the significantly longer length of the active phase for glaciers in the archipelago, which may also typify other high polar ice masses. The finding that surge behaviour, in the form of active-phase duration, shows systematic differences between different regions and their environments has important implications for understanding the processes responsible for glacier surges.
\end{abstract}

\section{INTRODUCTION}

Surge-type glaciers are those which exhibit cyclical instabilities related to changes intrinsic to the glacier system rather than to external forcing factors such as climate change (e.g. Meier and Post, 1969; Post, 1969; Raymond, 1987). Relatively short phases of fast flow (i.e. surges), often associated with crevassing and rapid terminus advance, repetitively punctuate significantly longer periods of quiescence and stagnation. During periods of stagnation, mass builds up through accumulation in an upper reservoir area, to be transferred rapidly down-glacier during the active phase. A number of theories have been proposed to account for the phenomenon of glacier surging (e.g. Clarke and others, 1984; Kamb and others, 1985; Fowler, 1987; Kamb, 1987). Most have in common the requirement for water build-up at the ice-bed interface, associated with re-organization of the basal drainage system around the time of the surge, in order for rapid flow to take place. Surges have been observed to occur at scales ranging from small valley glaciers to large ice-cap outlets, with the active phase typically lasting from a few months to less than 2 years.

A relatively large number of glaciers and ice caps in the Svalbard archipelago (Fig. 1) have been observed to surge (e.g. Liestøl, 1969; Schytt, 1969; Drewry and Liestøl, 1985; Dowdeswell, 1986a, b; Hagen, 1987; Liestøl, in press). The largest surge event so far observed anywhere was that of Bråsvellbreen on Nordaustlandet, whose advance around 1936 covered about $600 \mathrm{~km}^{2}$ of previously unglacierized area (Schytt, 1969). We have noted during both field and remote-sensing studies of Svalbard ice masses that a number of recent surges appear to have an active phase of particularly long duration relative to surges in other regions from which observations are available. Any systematic differences in surge duration between Svalbard glaciers and those elsewhere should be a reflection of: (i) the differing rates of operation of basal 


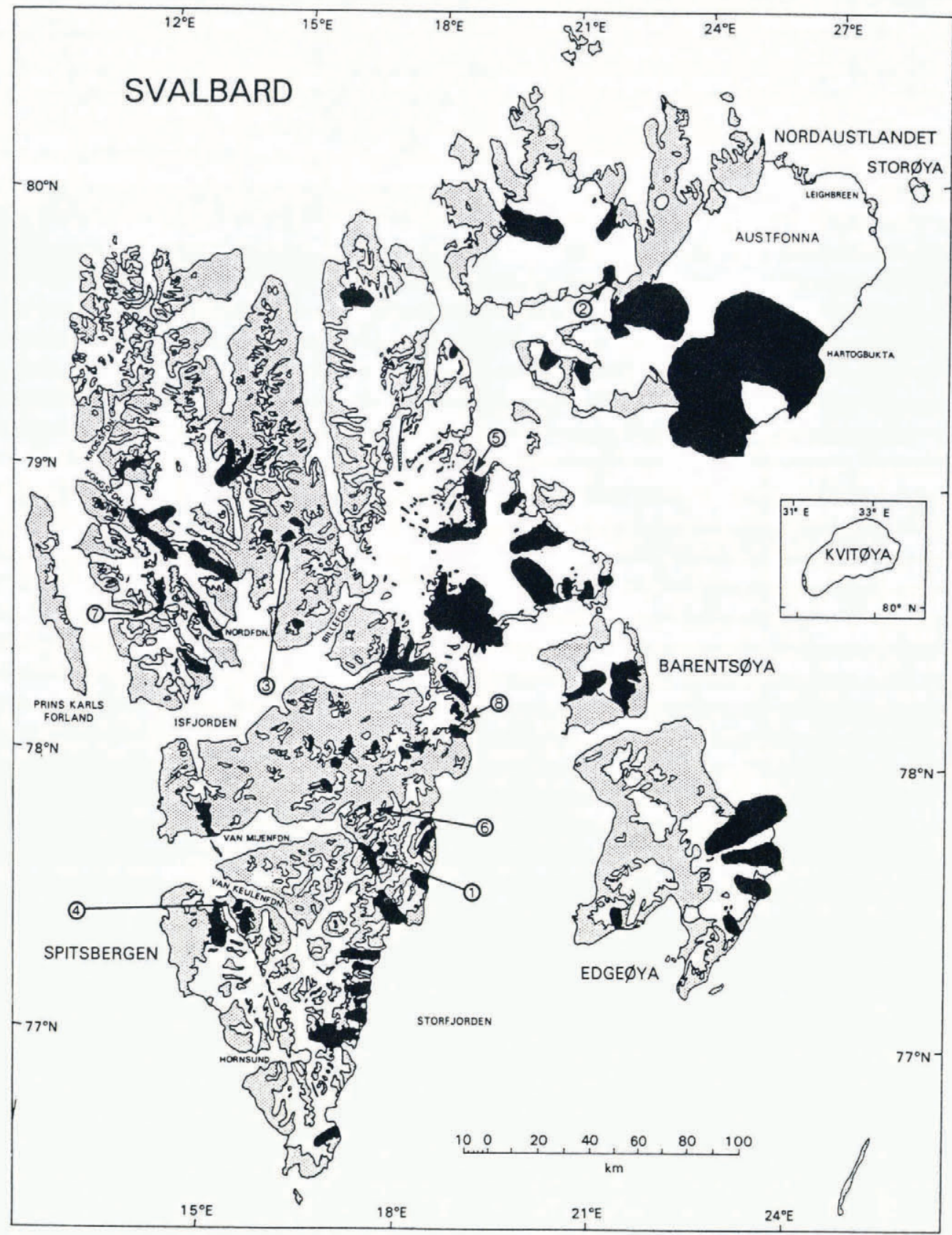

Fig. 1. Map of Svalbard giving the locations of the known surge-type glaciers in the archipelago (in black). Each of the eight surge-type glaciers for which surge-duration data are available (Table 1) are indicated by a circled numeral: 1, Bakaninbreen; 2, Bodleybreen; 3, Fyrisbreen; 4, Hessbreen; 5, Hinlopenbreen; 6, Hyllingebreen; 7, Osbornebreen; and 8, Usherbreen.

processes; (ii) the operation of different kinds of basal processes; or (iii) a combination of the above. The aim of this paper is to test the hypothesis that surge-type glaciers in the Svalbard archipelago have significantly longer active phases than glaciers in other regions for which data are available. This requires a systematic review of existing reports on surge activity in both Svalbard and other polar and mountain areas, combined with our own field and satellite studies of Svalbard glaciers. Detailed time series of observations through the active phase of the surge cycle are presented for several ice masses in Svalbard. These give evidence on, for example, the rate of down-glacier propagation of the surge front. Finally, some possible causes for the unusual length of surges on a number of Svalbard ice masses are suggested.

\section{DATA SOURCES AND METHODS}

Ice masses in many polar and mountain areas have been observed to surge. Still more have been inferred to be of surge-type, based on surface morphological characteristics such as the presence of sets of looped moraines (e.g. Meier and Post, 1969; Post, 1969). However, the number of glaciers for which the duration of the active phase is known is small. This is because observations of both surge inception and termination are required, but the occurrence of a surge is often inferred on the basis of a single observation from, for example, a field visit or an aerial photograph. A time series of observations through the active phase is required in order to measure the duration of the surge. Such data sets are available for only a small 
sub-set of the total number of surge-type glaciers in Svalbard and elsewhere. This point is illustrated in Figure 1 , in which all the ice masses in Svalbard known to surge are indicated, together with the eight glaciers for which data on surge duration are available.

The nature of most time-series data for surge-type glaciers also precludes the resolution of surge duration to the nearest month or few months. For example, an annual glacier survey during summer may show that a surge has begun since the previous year, but will not give a more precise date for inception. There are certain exceptions to this, such as the surge of Variegated Glacier in 1982-83, where velocity values were recorded quasi-continuously before, during and after the active phase (Kamb and others, 1985). These problems of temporal resolution constrain the accuracy of most surge-duration values to about a year and we, therefore, report the length of the active phase in years.

When beginning the examination of existing reports on surge-type glaciers, we had also intended to extract information on: (i) whether surge inception was, as some theories of surging suggest, predominantly during winter in response to changes in the basal drainage network (Raymond and Harrison, 1986); and (ii) the length of the quiescent period between surge activity. However, the temporal resolution of reports of surging precluded the pinpointing of surge inception to the nearest month or few months in all but a very few cases (e.g. Echelmeyer and others, 1987). A brief summary of the few data on quiescent-period length for Svalbard ice masses is given below.

\section{Svalbard surge-type glaciers}

Information on the duration of the active phase for Svalbard surge-type glaciers is derived from several sources. First, there are existing reports of glacier surges, often based on field reconnaissance or the interpretation of aerial photographs and satellite imagery (e.g. Liestøl, in press). Secondly, there are our continuing observations of Svalbard surge-type glaciers. These utilize field observations and reconnaissance flights, Landsat and SPOT photographic and digital satellite imagery, and the aerialphotograph collections held at the Norsk Polar-institutt, Oslo. In a number of cases, time series of glacier behaviour are reconstructed through the intercomparison of several of these types of data.

We also set up criteria, based on those of Meier and Post (1969), in order to establish that each of the Svalbard ice masses discussed in this paper conforms to the usual definition of a surge-type glacier. These criteria include: (i) the speed of ice flow is at least an order of magnitude greater during the surge than in the quiescent period; (ii) surges often, but are not required to, result in advance of the glacier terminus; (iii) an ice reservoir and ice-receiving area are present, and mass is transferred from the former to the latter during the surge, with significant surface lowering in the reservoir area; (iv) the ice surface becomes heavily crevassed during the surge, and is relatively free of crevasses during quiescence; (v) the active phase of the surge cycle is short relative to the quiescent period. Each Svalbard glacier discussed in the following sections meets all or most of these criteria. Where a criterion is not met, it is due to lack of data rather than to violation of that criterion. By adopting a definition of surge behaviour similar to that proposed by Meier and Post (1969), we believe that we can proceed to make useful comparisons with the duration of the active phase on surge-type glaciers in a number of other areas of the world.

\section{Surge-type glaciers in other areas}

In other areas, field studies, aerial photographs and, more recently, satellite-image analysis provide information on the length of the active phase on surge-type glaciers. The scientific literature on surge-type glaciers was searched for information on the duration of the active phase. Where the authors expressed reservations as to whether reported events were surges, these were excluded from our study. Surge events apparently caused by an obvious external influence, rather than processes intrinsic to the glacier, were also omitted from this study. For example, Soviet researchers have documented rapid glacier advances rsulting from volcanic activity in Kamchatka (Murav'yev and others, 1987). The 1964 Alaska earthquake caused a number of glaciers to be covered by rockslides which were followed by marked advances in their terminal position (Post, 1965, 1967). These have also been excluded from the present study.

For those glaciers unequivocally of surge type, the most common problem was the lack of a time series of observations of sufficient resolution to pinpoint both surge inception and termination. The duration of the active phase for the vast bulk of surge-type glaciers remains unknown for this reason. For example, Stanley (1969) described a surge of Steele Glacier in the Yukon, but was unable to state the duration of activity because the surge began before the first field observations were made. Similarly, many of the surges reported by Tarr and Martin (1914) from Alaska were active for unknown lengths of time, such as those of Lucia and Atrevida Glaciers which both terminated their surges before return field visits were made some years later.

Lack of temporal resolution for surge-type glaciers identified from aerial photographs also accounts for the apparent omission of data from surge events in many locations. Post (1960) described surges of a number of Alaskan glaciers which were noted from sequences of aerial photographs taken more than 10 years apart, long after any surge inferred from the previous photographs had ceased. Weidick (1988) reported surge activity by several Greenland glaciers during the 1980 s as observed from aerial photographs. However, the time series is again insufficient to resolve the length of active-phase duration. In addition, surges have been reported on Otto Glacier, Ellesmere Island (Hattersley-Smith, 1969), and on Good Friday Glacier, Axel Heiberg Island (Müller, 1969), although neither author was able to state the duration of the active phases.

A total of 36 surge-type glaciers from northwest North America, Iceland and several mountainous regions (excluding Svalbard) was found to yield information on surge duration. There is a clear lack of data on surge duration from High Arctic areas, apart from Svalbard. The Canadian Queen Elizabeth Islands, Greenland and the Soviet Arctic archipelagos of Franz Josef Land and 
Severnaya Zemlya are unrepresented. In terms of their sub-polar thermal structure and relatively low accumulation rates, one might predict that any surge-type glaciers from these areas would behave in a manner similar to those from Svalbard, but there is no evidence to test this hypothesis at present. In general, the number of known and reported surge-type glaciers far exceeds the number used in the present study. However, the necessarily stringent selection procedure employed accounts for the apparently small sample population.

\section{LONG-DURATION SURGES IN SVALBARD: EXAMPLES}

Four surge-type glaciers in Svalbard (Fig. 1), which have relatively long active phases, are now discussed in some detail, and other glaciers in the archipelago for which the duration of the active phase is known are given in Table 1. The four glaciers discussed are selected because of the time series of data available for each of them and because of their varied nature: two are ice-cap outlet glaciers and two are valley glaciers; two end in tide water and two on land. Descriptions vary between these glaciers, depending on the available data sources. These examples are presented for several reasons. First, they demonstrate that we are indeed documenting surge-type activity. Secondly, they illustrate the rate of operation of parameters such as surgefront propagation, ice-surface velocity and glacier advance associated with surge activity in Svalbard. When combined with tabulated information for several other Svalbard glaciers, these examples demonstrate that an active phase of long duration relative to other areas is characteristic of a number of surge-type glaciers in Svalbard. There are no reports of Svalbard surge-type
Table 1. Duration of the active phase of the surge cycle for Svalbard glaciers. Glacier locations are given in Figure 1. Length and area measurements are for pre-surge glacier configurations

Svalbard Length Area Duration Reference
glacier

$$
\mathrm{km} \quad \mathrm{km}^{2} \text { years }
$$

$\begin{array}{lrrrl}\begin{array}{l}\text { Bakaninbreen } \\ \text { Bodleybreen }\end{array} & 17 & 57 & 5+ & - \\ & 15 & 87 & 5+ & \begin{array}{l}\text { Dowdeswell, } \\ 1986 \mathrm{a}\end{array} \\ \begin{array}{l}\text { Fyrisbreen } \\ \text { Hessbreen }\end{array} & 3.5 & 3 & 8 & \text { Liestøl, 1969 } \\ \text { Hinlopenbreen } & 58 & 6 & 5 & \text { Liestøl, 1975 } \\ & 68 & 1250 & 4+ & \text { Liestøl, } \\ \text { Hyllingebreen } & 3 & 3 & 10 & - \\ \begin{array}{l}\text { Osbornebreen } \\ \text { Usherbreen }\end{array} & 20 & 152 & 3+ & - \\ & 12 & 29 & 8 & \text { Hagen, } 1987\end{array}$

glaciers with a shorter active phase than those mentioned in Table 1 .

\section{Bakaninbreen, central Spitsbergen}

Bakaninbreen is a valley glacier draining a basin of almost $60 \mathrm{~km}^{2}$. It is $17 \mathrm{~km}$ long and for its lower $6.5 \mathrm{~km}$ it joins the larger Paulabreen, the boundary between the two being marked by a medial moraine (Fig. 2). Bakaninbreen

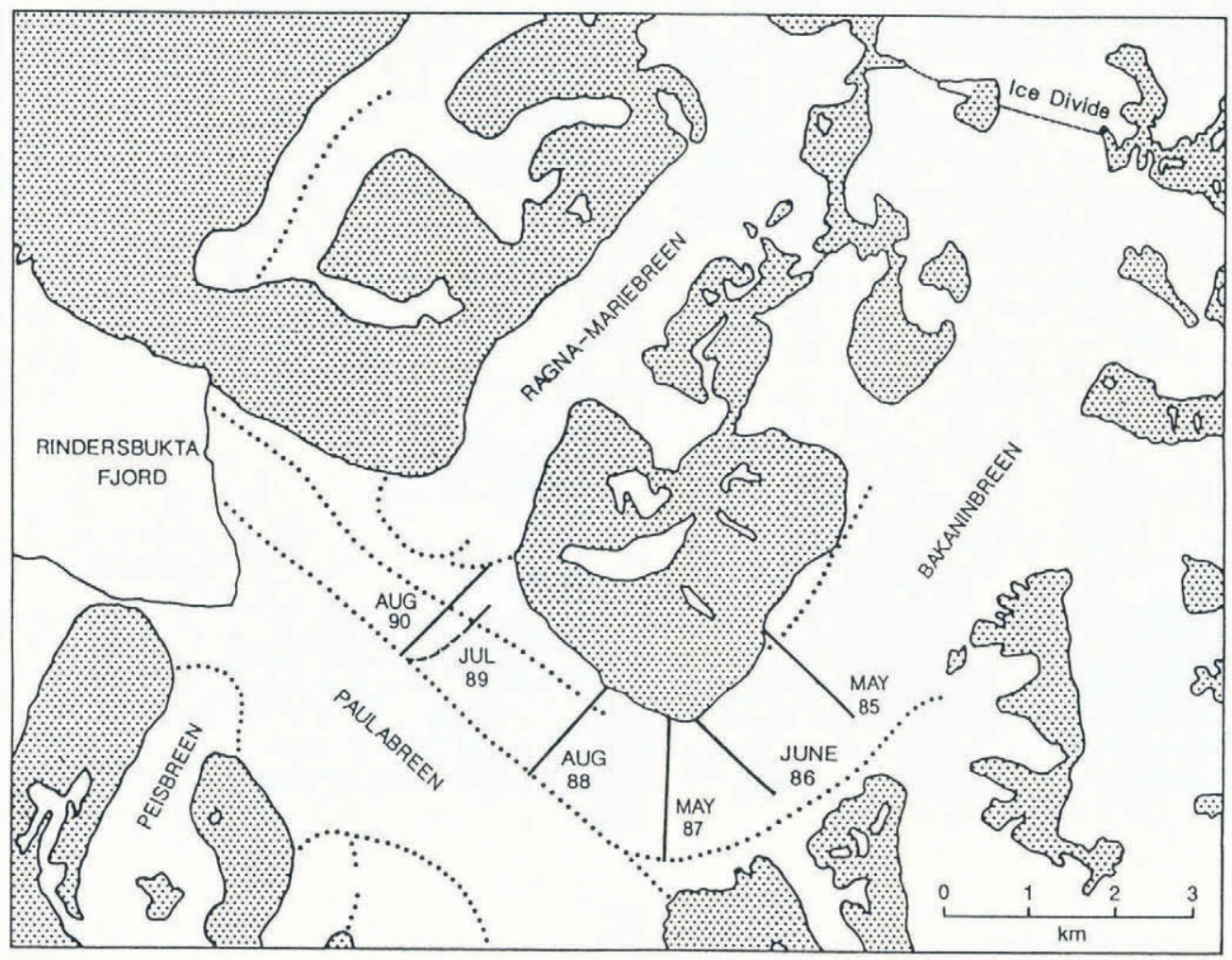

Fig. 2. Map of Bakaninbreen and adjacent glaciers, with the dates and down-glacier propagation of the surge front shown. The location of Bakaninbreen within Svalbard is shown in Figure 1. 


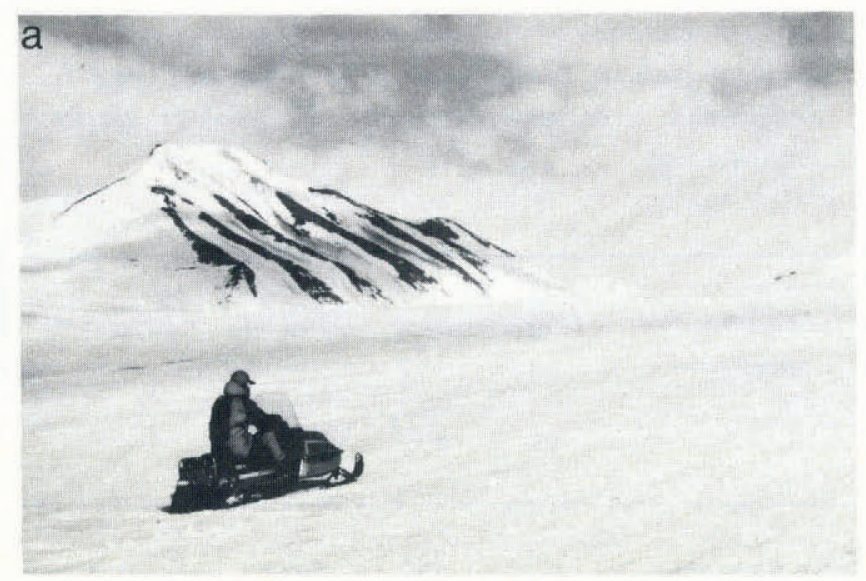

Fig. 3. The upper part of Bakaninbreen. (a) Uncrevassed ice surface above the ice ramp in May 1985. (b) The heavily crevassed surface in May 1987. Note the down-draw of ice in

terminates on land at present, and the margin of Paulabreen ends in shallow fjord waters. Comparison of oblique and vertical aerial photographs acquired by the Norsk Polarinstitutt in 1936, 1961, 1970 and 1977 shows that the termini of both Paulabreen and Bakaninbreen have been retreating progressively over this period. A field visit to the glacier in May 1985 showed that a ramp of steep gradient $\left(6^{\circ}\right)$ was present at $7 \mathrm{~km}$ from the ice divide marking the upper extent of the drainage basin (Fig. 2).

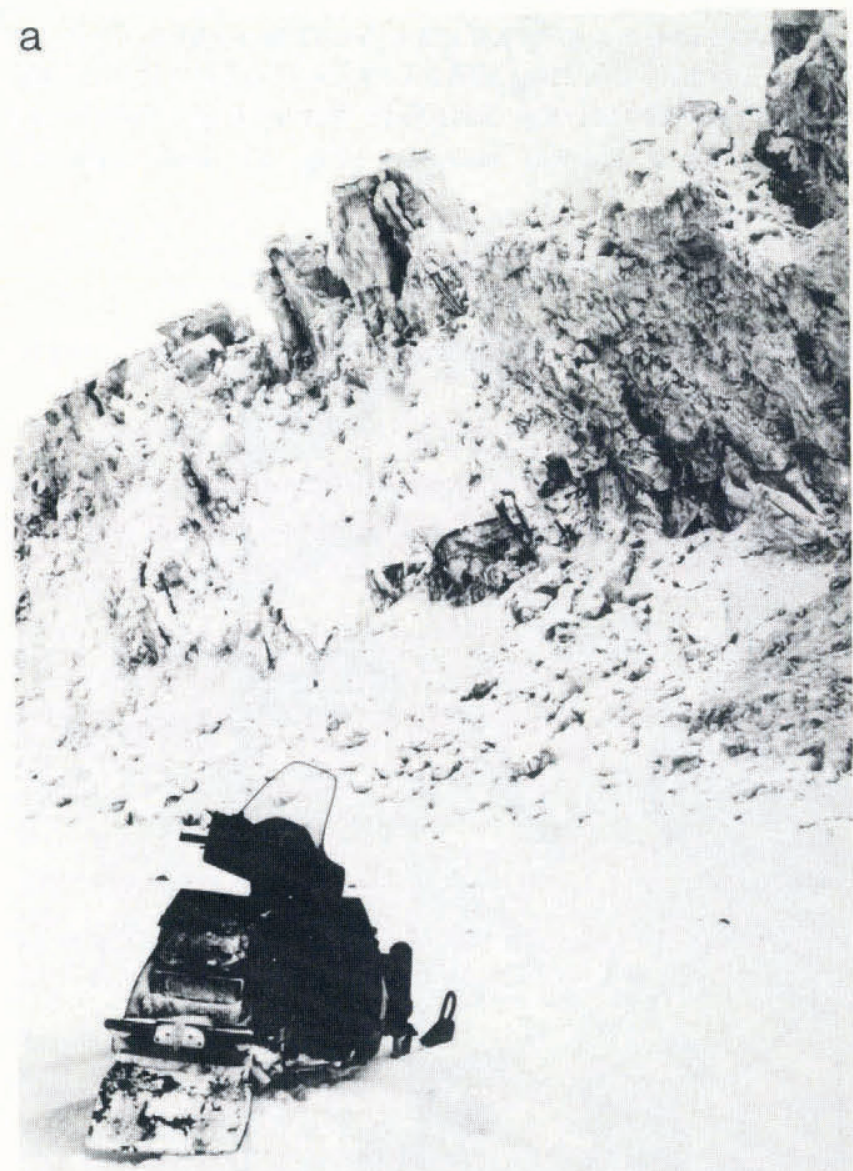

b

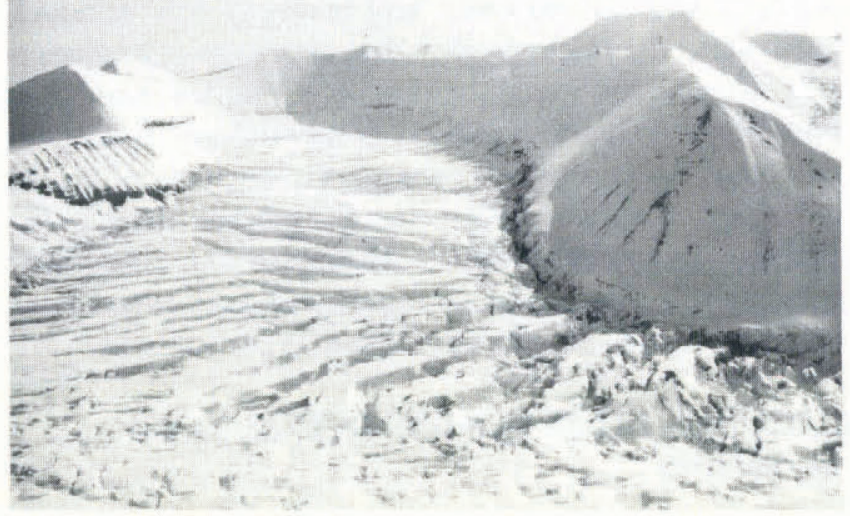

the upper basin associated with rapid transfer of mass from the reservoir area during the surge.

Limited crevassing was present on the ramp crest. Icesurface velocity close to the top of the ramp was $0.24 \mathrm{~m} \mathrm{~d}^{-1}$ and longitudinal compressive strain rates of up to 1.2 year $^{-1}$ were recorded at its base. In contrast, below the ramp, velocity was close to zero. Little crevassing was present further up-glacier and there was no sign of ice down-draw (Fig. 3a).

By 1986 the situation had changed considerably and a surge is inferred to have begun between spring 1985 and

b

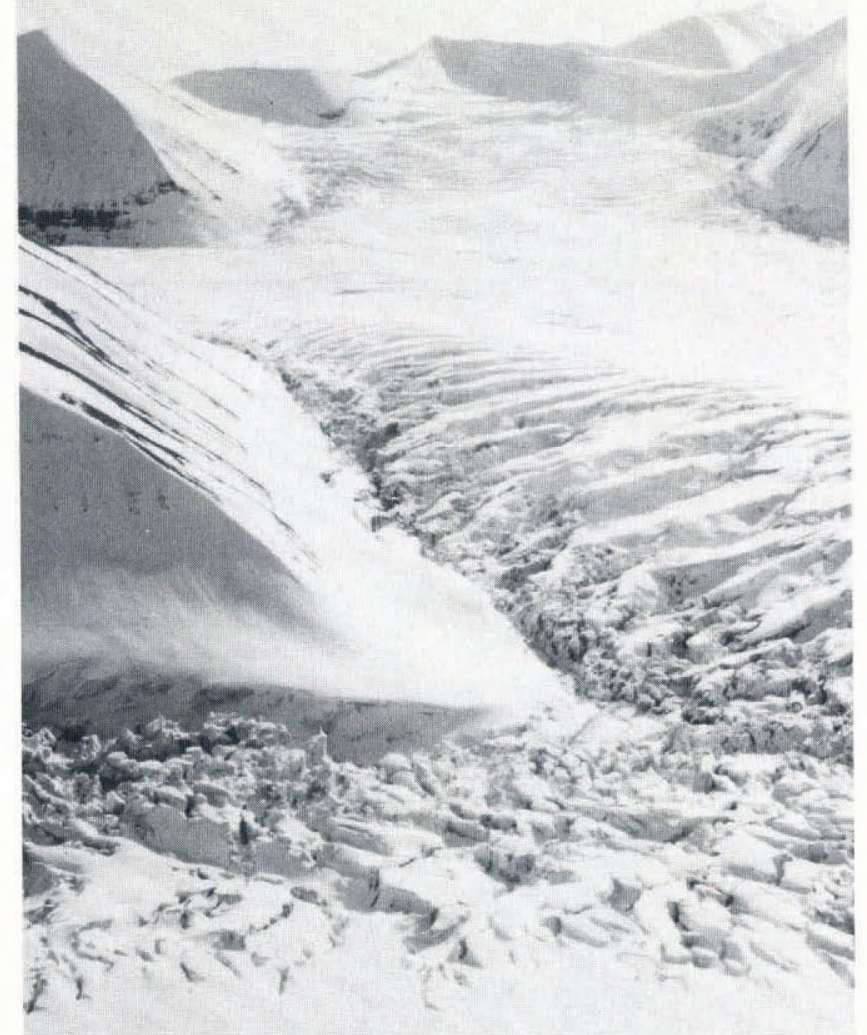

Fig. 4. The lower part of Bakaninbreen. (a) The advancing surge front in May 1987. (b) Heavy crevassing behind the advancing surge front in May 1987. 
the next visit in March 1986. Velocities of between 0.9 and $3.0 \mathrm{~m} \mathrm{~d}^{-1}$ were recorded at and immediately behind the surge front between March and September 1986. Vertical elevation changes over this period are also consistent with down-glacier propagation of a surge front. Ice-surface uplift rates of up to $0.3 \mathrm{~m} \mathrm{~d}^{-1}$ were associated with the passage of the surge front. Between May 1985 and June 1986 the surge front advanced $1.3 \mathrm{~km}$, a rate of just over $3 \mathrm{~m} \mathrm{~d}^{-1}$. The morphology of the 1986 surge front was that of a near-vertical wall of highly crevassed ice, which was over-riding the stagnant ice below (Fig. 4a). This contrasted with the sloping ramp of the previous spring. In the upper part of Bakaninbreen and its tributaries, heavy crevassing was present over a surface, that had been easily traversed by snowmobile in May 1985 (Fig. 3b). There was also considerable evidence of ice down-draw along the valley walls in the upper glacier, where the ice surface had clearly fallen in elevation as mass was transferred rapidly down-glacier (Fig. 3b).

The position of the surge front has also been recorded from reconnaissance flights over the glacier in May 1987, August 1988, July 1989 and August 1990 (Figs 2 and 4b). Propagation distances of $1.3,1.7$ and $0.4 \mathrm{~km}$ were estimated between these observations. The surge front therefore advanced down-glacier at a rate of between 1 and $5 \mathrm{~m} \mathrm{~d}^{-1}$ over this period. Surge inception occurred between May 1985 and March 1986. The surge has been continuing for a minimum of over 4 years, and is still in progress (August 1990).

\section{Bodleybreen, Vestfonna, Nordaustlandet}

Bodleybreen is an outlet glacier of the Vestfonna ice cap $\left(2500 \mathrm{~km}^{2}\right)$ on Nordaustlandet in eastern Svalbard (Figs 1 and 5). It drains an area of almost $90 \mathrm{~km}^{2}$, is $15 \mathrm{~km}$ long and ends in tide water. It, together with three other drainage basins of Vestfonna, represents a set of welldefined outlet glaciers, clearly separated from the more stagnant ice ridges between them (Dowdeswell and Collin, 1990). Crevasses have been observed over much of the glacier since the earliest oblique aerial photographs were collected in 1938, indicating that the glacier was not completely stagnant even during the quiescent period.

Vertical aerial photographs of Bodleybreen are available for 1970, 1971 and 1977, together with Landsat computer-compatible tapes (CCTs) for 1973, 1976, 1980, 1981 and 1984. Between 1970 and 1971, the glacier terminus advanced a mean distance of about $100 \mathrm{~m}$. Between 1971 and 1977, a marked change in the pattern of surface crevassing, a lowering of the ice surface in the upper glacier and a terminus advance of $1.2 \mathrm{~km}$ took place (Dowdeswell and Collin, 1990). The glacier also thickened by between 10 and $60 \mathrm{~m}$ in its lowest $3 \mathrm{~km}$ between 1970 and 1977. These data, derived from detailed photogrammetric analysis of aerial photographs, show that a surge was initiated between 1971 and 1977. Digitally enhanced Landsat imagery augments the time series of aerial photographs. Between 1973 and 1976, the mean advance across the whole ice front was $520 \mathrm{~m}$, and a maximum of $780 \mathrm{~m}$ in certain areas (Dowdeswell, 1986b). From 1976 to 1981 (Fig. 5), advances of the terminus were $2200 \mathrm{~m}$ (mean) and $2900 \mathrm{~m}$ (maximum), indicating that the surge was still in progress. By the summer of 1984 it was clear

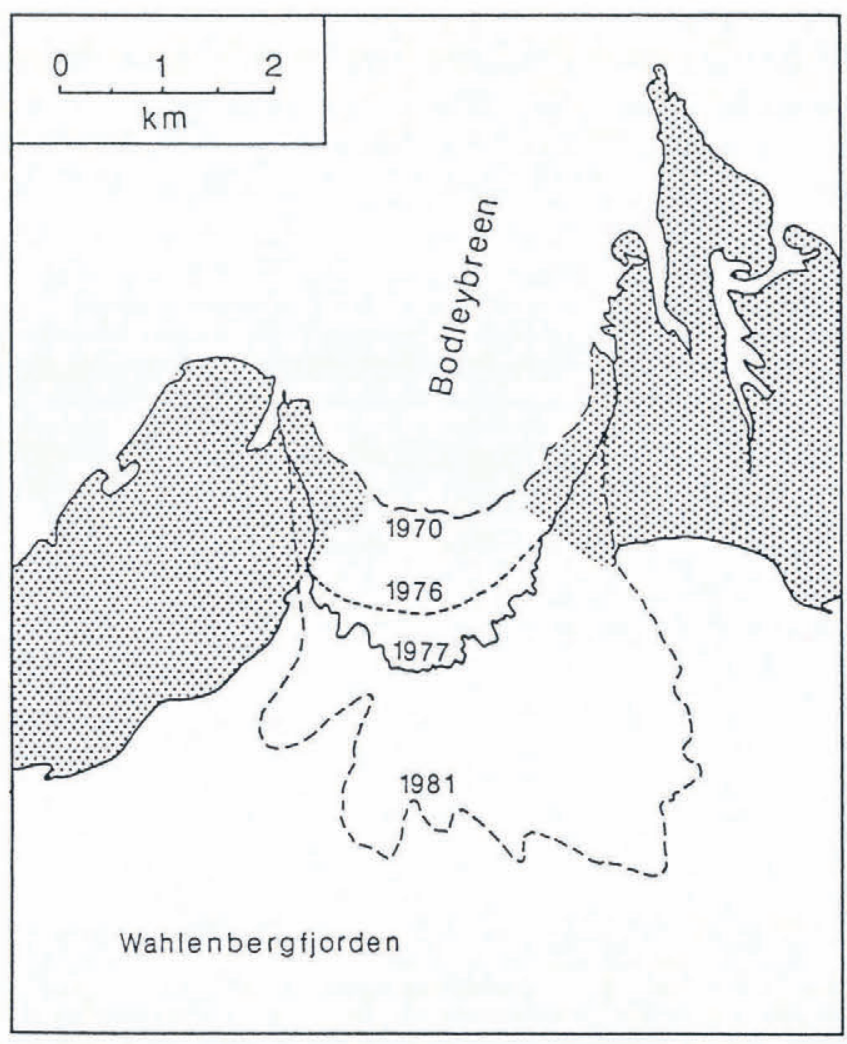

Fig. 5. Map of Bodleybreen on Vestfonna, Nordaustlandet (Fig. 1), showing the advancing terminus between its presurge position in 1970 and during its surge in 1976, 1977 and 1981.

from enhanced Landsat data that the surge was over, because the ice front had begun to retreat significantly.

The dating of both surge initiation and termination can only be bracketed using the available remote-sensing sources. Surge initiation between 1971 and 1976, combined with termination between 1981 and 1984, gives minimum and maximum surge durations of 5 and 13 years, respectively. Our best estimate of actual surge duration on Bodleybreen is 7 years.

\section{Usherbreen, eastern Spitsbergen}

Usherbreen is an outlet glacier from the ice cap of Nordmannsfonna in eastern Spitsbergen (Fig. 1). The glacier, prior to its surge, was $12 \mathrm{~km}$ long with an area of $29 \mathrm{~km}^{2}$. The average ice-surface slope of the lower glacier was $2.5^{\circ}$, characteristic of the low gradients exhibited by most surge-type glaciers during the quiescent phase. Vertical aerial photographs were obtained in 1971 and Landsat satellite images from 1978 and 1980 are available. Usherbreen was also field surveyed and mapped in 1985 (Hagen, 1987).

Analysis of Landsat imagery showed that the terminus of Usherbreen began to advance in 1978. By 1980, the ice front had moved forward about $1 \mathrm{~km}$, implying an average rate of advance of more than $1.3 \mathrm{~m} \mathrm{~d}^{-1}$. The terminus continued to advance, but at a slower rate, between 1980 and 1985 . By the summer of 1985 ice-surface velocity had decreased to $0.15 \mathrm{~m} \mathrm{~d}^{-1}$. This value is still significantly higher than that of the stagnant terminus regions typical of surge-type glaciers in the quiescent phase between 
surges. However, velocity decreased through the summer of 1985 and this is, therefore, taken to be the last year of the active phase. The duration of this surge of Usherbreen was thus 8 years. The long period over which velocities slowed down at Usherbreen contrasts markedly with the situation at Variegated Glacier, Alaska, where the surge termination took place over only $2 \mathrm{~d}$ (Kamb and others, 1985).

\section{Osbornebreen, St. Jonsfjorden, western Spitsber- gen}

Osbornebreen is a tide-water glacier terminating in St. Jonsfjorden, western Spitsbergen (Fig. 1). The glacier was $20 \mathrm{~km}$ long before it surged and drained an area of $152 \mathrm{~km}^{2}$. Its basin includes a number of small tributary glaciers. A $6 \mathrm{~km}$ long ridge of mountains divides Osbornebreen into two major flow units for much of its length (Fig. 6).

Landsat satellite images from 1986, 1987 and 1988 record the initiation and early development of the surge of Osbornebreen. The glacier was devoid of major crevasses in August 1986. During the winter of 1986-87, a surge was initiated on the western flow unit, which is about $3 \mathrm{~km}$ wide for most of its $20 \mathrm{~km}$ length (Fig. 6). By April 1987, field observations showed that the glacier had advanced

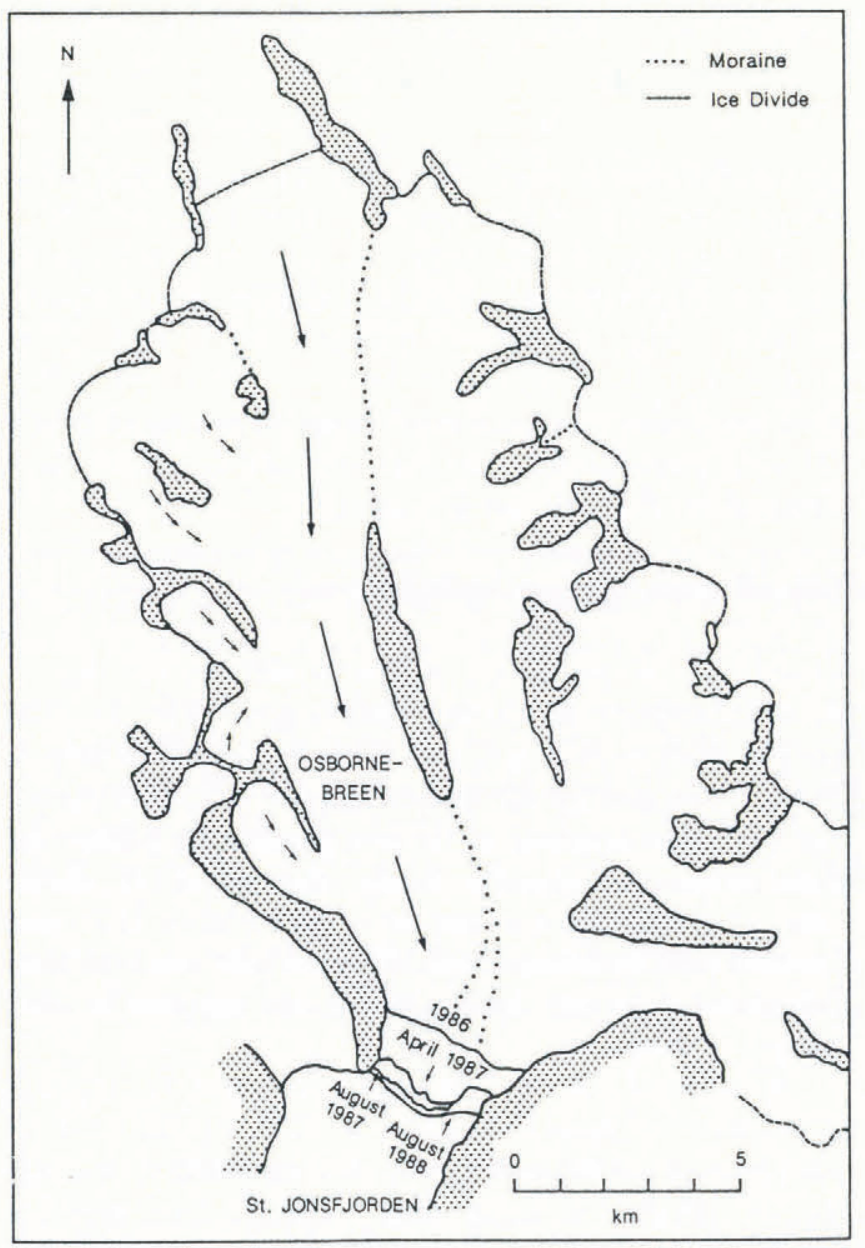

Fig. 6. Map of Osbornebreen (Fig. 1), defining the area affected by the surge (arrows indicate flow direction). The position of the advancing ice front is also shown for several dates. by $1.4 \mathrm{~km}$ into the fjord. We do not know at what point during the winter Osbornebreen began to surge but, if rapid motion was initiated as early as September or October 1986, an average speed for the surge front was a minimum of 6-7 $\mathrm{m} \mathrm{d}^{-1}$. From April to August 1987, the glacier terminus moved forward by a further $0.3 \mathrm{~km}$ or about $2.5 \mathrm{~m} \mathrm{~d}^{-1}$. The medial moraine between the western and eastern flow units was also deflected about 600-700 m to the southeast, reflecting the lack of any surge on the eastern flow unit of Osbornebreen (Fig. 6).

By April 1987, only the trunk of the western flow unit was affected by crevassing indicative of fast flow. However, by August, small tributaries in the upper drainage basin of Osbornebreen had also been affected, as the area of heavily crevassed ice propagated into the upper accumulation area of the glacier. The total area affected by rapid surge motion was $65 \mathrm{~km}^{2}$. Landsat inagery from August 1988 indicated that the tide-water terminus continued to advance further into the fjord and was just outside its August 1987 position. Direct observations from a helicopter during April 1990 showed that the glacier was still advancing and active, with a very heavily crevassed surface. However, further surveying of the ice front was not possible during the reconnaissance.

These field and remotely sensed observations of Osbornebreen indicate an abrupt initiation of the surge, with very high velocities during its first few months. Velocity then decreased, but remained significantly in excess of that observed in quiescent-stage, stagnant surgetype glaciers. Osbornebreen has, therefore, been surging for at least 3.5 years (to April 1990) and there is as yet no evidence that the rapid-motion event has terminated.

\section{Other Svalbard glaciers}

Less detailed observations on the duration of surges are available for four other Svalbard ice masses. The large outlet glacier Hinlopenbreen (area $1250 \mathrm{~km}^{2}$ ) in northeast Spitsbergen (Fig. 1) was imaged by aerial photographs in 1969, 1970 and 1971. The 1969 photographs do not cover the tide-water terminus, but the upper and middle part of the outlet glacier was already highly crevassed, and some tributaries were also affected. This suggests that the surge is likely to have begun at the latest in 1968. Ice velocity at the centre line of Hinlopenbreen between August 1969 and August 1970 was $16 \mathrm{~m} \mathrm{~d}^{-1}$, averaged over the year, and the ice front advanced about $3 \mathrm{~km}$ (Liestøl, 1971). Between 1970 and 1971 the tide-water ice front continued to advance, and velocities at the crevassed ice surface were measured at $14 \mathrm{~m} \mathrm{~d}^{-1}$ (Liestøl, 1972). No observations are available for a number of years after this date, but the surge lasted a minimum of 4 years.

Hyllingebreen, a small, north-facing valley glacier of about $3 \mathrm{~km}^{2}$ in Kjellströmdalen, central Spitsbergen (Fig. 1), was $3 \mathrm{~km}$ long prior to its surge. Oblique aerial photographs of the glacier were obtained in 1936, and vertical photographs in 1960, 1970 and 1977. In addition, field surveys of Hyllingebreen were carried out in 1985 and 1986 (Hagen, 1988). Comparison of 1936 and 1960 photographs showed that steady down-melting and retreat of the lower part of the glacier took place over this period. A reconnaissance visit to the area in spring 1968 mapped the position of the ice front. By 1970, aerial 
photographs showed that the ice surface was heavily crevassed and the surge front was steep and well definea. The ice front advanced by $400 \mathrm{~m}$ over this period. Between 1970 and 1977 the ice surface remained crevassed and the terminus advanced a further $600 \mathrm{~m}$ at an average of $85 \mathrm{~m} \mathrm{a}^{-1}$. By the time of the 1985 field survey an additional $200 \mathrm{~m}$ of advance had occurred. This was probably achieved in the late 1970s. The maximum length of the glacier after the surge was $4.5 \mathrm{~km}$, an increase of $1.5 \mathrm{~km}$ over the pre-surge length. The ice was largely stagnant by the time of the 1985 and 1986 surveys, indicating that the glacier had returned to quiescence. The surge lasted, therefore, for a minimum of about 10 years from 1968 to at least 1978.

On the $5 \mathrm{~km}$ long Hessbreen $\left(6 \mathrm{~km}^{2}\right)$ in Van Keulenfjorden (Fig. 1), Liestøl (1975, personal communication) made surveys in 1970 and 1974 and reconnaissance observations in the years following this. A surge was initiated in 1972 and the length of the active period was 5 years.

In the late 1950 s a small glacier in Dicksondalen (Inner Isfjorden), known as Fyrisbreen (Fig. 1), developed a broken surface and began to advance. Aerial photographs from 1960 and field reconnaissance in 1962 showed that the glacier was heavily crevassed and advancing at a rate of about $40 \mathrm{~m} \mathrm{a}^{-1}$ (Liestøl, 1969). 1966 aerial photographs indicated that the surge terminated at about this time. The surge lasted, therefore, about 8 years.

\section{Quiescent-period length}

There are very few records of quiescent-period length for Svalbard ice masses, despite coverage of the entire archipelago by oblique aerial photographs as early as the mid-1930s and reconnaissance glaciological observations from earlier in the 20th century. Based on observations of more than one surge of a given ice mass, Liestøl (in press) reported quiescent-period lengths for only three Svalbard glaciers: 50 years for Tunabreen, 70 years for Hambergbreen and 110 years for Recherchebreen. Using arguments based on the amount of mass transfer from reservoir to receiving area, combined with mass-balance data, the quiescent periods of two drainage basins on Austfonna, Nordaustlandet (Fig. 1), have also been calculated as 130-140 years and 370-510 years (Solheim, in press). Schytt (1969) also estimated the quiescent period of one of these surge-type basins at in excess of 200 years. This evidence suggests that the quiescent phase between surges is long for Svalbard glaciers in comparison with, for example, those in northwest North America and the Pamirs. In these other areas, several ice masses have been observed to surge about everv 20-40 years (e.g. Dolgushin and Osipova, 1975; Kamb and others, 1985).

These differences in surge-return period are related to the slower rate at which mass builds up in the accumulation area of Svalbard glaciers during the quiescent phase (where the net accumulation is often only 0.3$0.6 \mathrm{~m} \mathrm{a}^{-1}$ of water equivalent, e.g. Dowdeswell and Drewry, 1989; Hagen and Liestøl, 1990), relative to that in parts of northwest North America and the Pamirs. Any differences in the amount of down-draw in the reservoir areas of surge-type glaciers will also affect the length of the quiescent period, but data from Svalbard are few.
Measurements on several glaciers (e.g. Usherbreen, Bakaninbreen) show a drop in the surface elevation of the reservoir area in excess of $50 \mathrm{~m}$ during surges, but these data do not necessarily reflect change over the full duration of the active phase and are thus difficult to compare with evidence from other regions.

\section{SURGE DURATION: DISCUSSION}

\section{Svalbard}

The eight Svalbard ice masses in Table 1 have surge durations ranging from at least 3 up to 10 years. One glacier is still in the active phase of the surge cycle and three others were still active when the available time series of observations terminated. Thus, the surge durations for four of the eight glaciers in Table 1 (marked with "+" signs) are minimum values.

The velocities recorded during the surges of these Svalbard glaciers varied between a maximum of $16 \mathrm{~m} \mathrm{~d}^{-1}$ for Hinlopenbreen and about $0.2 \mathrm{~m} \mathrm{~d}^{-1}$ during the latter part of the active phases on Usherbreen, Hyllingebreen and Fyrisbreen. On Usherbreen, for example, velocities are highest shortly after surge initiation $\left(1.3 \mathrm{~m} \mathrm{~d}^{-1}\right.$ in 1980) and fall to lower values $\left(0.15 \mathrm{~m} \mathrm{~d}^{-1}\right.$ in 1985$)$ as the active phase proceeds. Throughout the active phase for each glacier, advance of the ice terminus continues and the ice surface remains heavily crevassed. There is a notable difference between this form of velocity pattern and that of a number of surge-type glaciers from elsewhere. For example, on the lower part of Variegated Glacier, Alaska, velocity climbed rapidly from zero to a peak of over $50 \mathrm{~m} \mathrm{~d}^{-1}$, and then fell very rapidly back to zero as the surge terminated about 2 months later (Kamb and others, 1985). Thus, surge velocities in Svalbard are relatively slow compared with many of the glaciers in Table 2. The transfer of mass from an upper reservoir area to a lower receiving area is, therefore, accomplished over a considerably longer period in the Svalbard cases. Nonetheless, advances of the termini of these Svalbard glaciers cannot be accounted for by climatic shifts to a positive mass balance, because mass-balance data from glaciers in several parts of the archipelago show consistently negative balances, and climate records for the region indicate no major shifts since the termination of the Little Ice Age at the turn of the century (Hagen and Liestøl, 1990; Lefauconnier and Hagen, 1990).

The rapidity with which surges terminate also differs between Svalbard and Alaskan glaciers. The surge of Usherbreen in Spitsbergen terminated slowly with a decrease in velocity towards quiescent-phase values occurring over several years. By contrast, very abrupt surge termination, over only a few days and linked to major changes in basal hydrology, was observed at Variegated and West Fork Glaciers in Alaska (Kamb and others, 1985; personal communication from W. D. Harrison). This raises very important questions concerning the time-dependent behaviour of the basal hydrological system betwen the two areas, and detailed studies of the hydrology of surge-type glaciers in Svalbard are clearly required. 


\section{Other regions}

The duration of the active phase of the surge cycle is given for 36 glaciers from a number of areas in Table 2. Over $80 \%$ of reports of glacier surges providing sufficient detail to establish active-phase length come from three regions: northwestern North America (Alaska, the Yukon and British Columbia), Iceland and the Soviet Pamirs. A small number of observations also come from the Caucasus, the Tien-shan and the Karakoram in Asia, and from the Andes in South America. This spatial distribution probably reflects the intensity of scientific study as well as any physical attributes of ice masses in these different areas.

The surge-duration data for areas excluding Svalbard show that over $85 \%$ of ice masses for which data exist have active phase lengths of less than 2 years (Table 2; Fig. 7). Three of the 36 glaciers surged for 3 years and only one (Walsh Glacier, Alaska) had a 4 year active phase. Within the data set, there is a trend for Alaskan and Yukon glaciers, together with those from the Pamirs, to have longer-duration surges than Icelandic glaciers and those few observed for other mountain regions. This is demonstrated by a comparison of the frequency distributions in Figure 7.
The length and area of the 36 ice masses in Table 2 were compared with the duration of the active phase to establish whether there were links between surge duration and these glacier size parameters. Regressions of both glacier length and area against surge duration yielded only weak positive relationships, with low $r^{2}$ values of 0.22 and 0.09 , respectively. These values are, however, strongly dependent on one outlier, Walsh Glacier. When this glacier is removed from the regression analysis, $r^{2}$ values drop to $<0.02$. Surge duration does not, therefore, appear to be dependent on parameters related to glacier size (cf. Post, 1969; Clarke and others, 1986). This finding also applies to the eight Svalbard surge-type glaciers listed in Table 1.

\section{Contrasting active-phase duration}

A comparison of frequency distributions for the duration of surges on Svalbard ice masses (Fig. 7e) with glaciers from other areas (Fig. 7a-d) shows that significant contrasts exist. A significant difference in the sample populations can be found with $99.9 \%$ confidence using a Student $t$-test. No documented surges in other areas exceed 4 years in duration, and only one lasts for even a fourth year (Fig. 7d). Two Svalbard surge-type glaciers
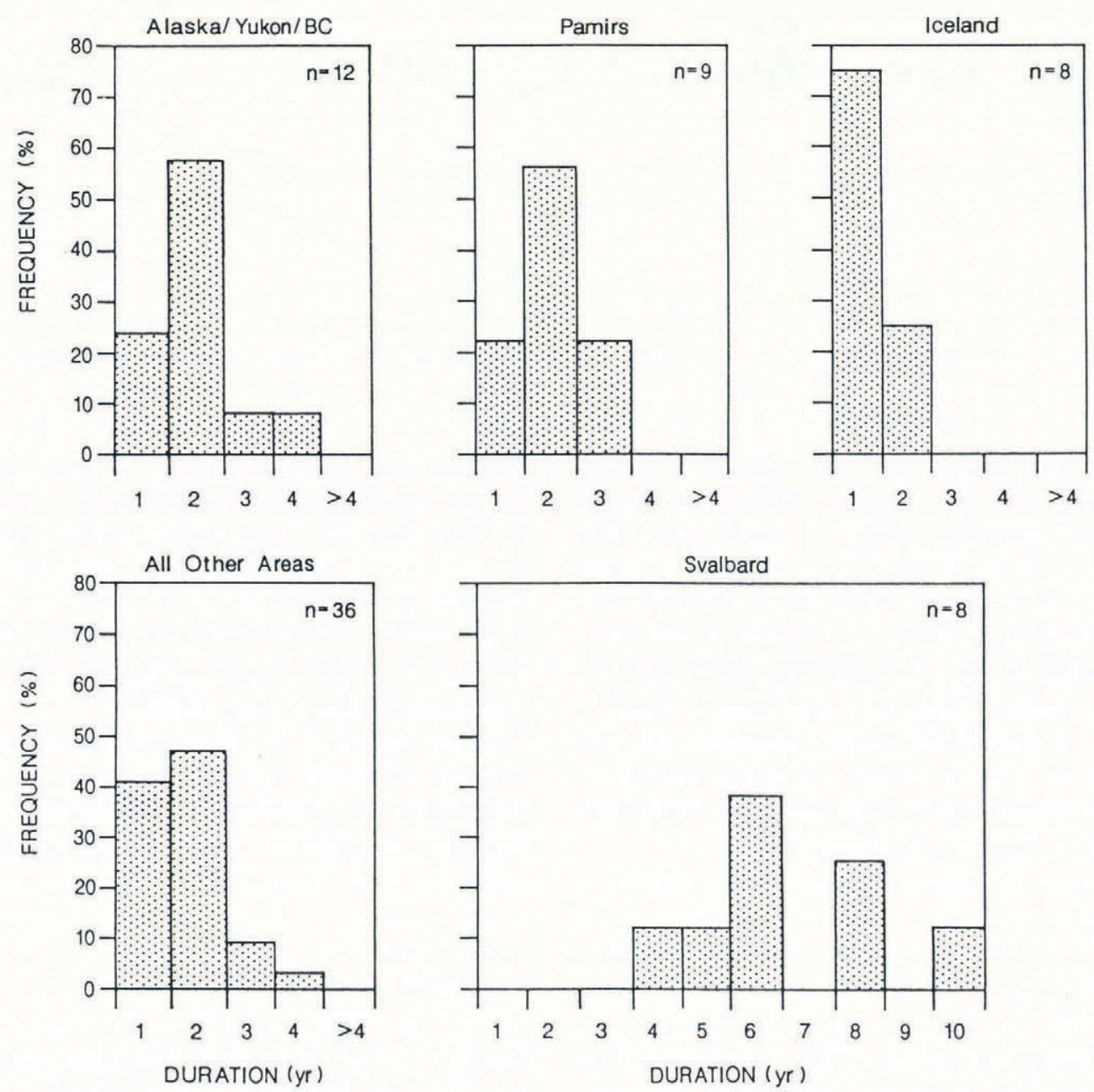

Fig. 7. Histograms of surge duration for glaciers in (a) northwest North America, (b) Pamirs, (c) Iceland, (d) all regions for which data are available combined but excluding Svalbard, and (e) Svalbard. 
Table 2. Duration of the active phase of the surge cycle for glaciers in other polar and mountain areas of the world. Note that length and area measurements are for pre-surge glacier configurations

\begin{tabular}{|c|c|c|c|c|}
\hline Glacier & $\begin{array}{c}\text { Length } \\
\text { km }\end{array}$ & $\begin{array}{l}\text { Area } \\
\mathrm{km}^{2}\end{array}$ & $\begin{array}{c}\text { Duration } \\
\text { years }\end{array}$ & Reference \\
\hline \multicolumn{5}{|l|}{$\begin{array}{l}\text { Alaska, Yukon Territory } \\
\text { and British Columbia }\end{array}$} \\
\hline Variegated, AK & 20 & 49 & 2 & Kamb and others (1985) \\
\hline Walsh, AK & 89 & 830 & 4 & Post $(1960)$ \\
\hline Muldrow, $\mathrm{AK}$ & 46 & 393 & 2 & Post (1960) \\
\hline Peters, AK & 27 & 120 & 2 & Echelmeyer and others (1987) \\
\hline Tikke, BC & 19 & 75 & 3 & Meier and Post (1969) \\
\hline Tyeen, AK & 7 & 11 & 2 & Field (1969) \\
\hline West Fork, AK & 41 & 311 & 1 & $\begin{array}{l}\text { Echelmeyer and Harrison (1989, personal } \\
\text { communication) }\end{array}$ \\
\hline Rendu, AK & 17 & 50 & 2 & Field (1969) \\
\hline Hazard, YT & 8 & - & 2 & Clarke and Collins (1984) \\
\hline Childs, AK & 19 & 20 & 1 & Tarr and Martin (1914) \\
\hline Unnamed, AK & 6 & - & 2 & Krimmel (1988) \\
\hline Black Rapids, AK & 45 & 341 & 1 & Moffit (1942) \\
\hline Carroll, AK & 42 & 200 & 1 & Smith (1990) \\
\hline \multicolumn{5}{|l|}{ Iceland } \\
\hline Sidujøkull & 40 & 350 & 1 & Thorarinsson (1964) \\
\hline Dyngjujøkull & - & - & 2 & Thorarinsson (1964) \\
\hline Tungnárjøkull & 25 & 120 & 1 & Thorarinsson (1964) \\
\hline Brúarjøkull & 50 & 1500 & 2 & Thorarinsson (1969) \\
\hline Eyjabakajøkull & 10 & 50 & 1 & Williams (1976) \\
\hline Teigadalsjøkull & 1 & 1 & 1 & Halgrímsson (1972) \\
\hline Hagafellsjøkull eystri & 17 & 110 & 1 & Sigbjarnarsson (1976) \\
\hline Hagafellsjøkull vestari & 17 & 100 & 1 & Theodórsson (1980) \\
\hline \multicolumn{5}{|l|}{ Pamirs and Caucasus } \\
\hline Medvezhiy & 13 & 25 & 1 & Dolgushin and Osipova (1975) \\
\hline Byrs & 2 & 10 & 2 & Rototayev (1983) \\
\hline Shini-bini & 10 & 16 & 2 & Uskov and Dil'muradov (1983) \\
\hline Sugran & 22 & 47 & 3 & Uskov and Dil'muradov (1983) \\
\hline Muzgazy & 11 & 16 & 2 & Desinov (1984) \\
\hline Abramova & - & - & 3 & Glazyrin and others (1987) \\
\hline Ravak & 3 & 2 & 1 & Dolgushin and Osipova (1975) \\
\hline Tanyrnas & 10 & 61 & 2 & Dolgushin and Osipova (1975) \\
\hline Burokurmas & 7 & 8 & 2 & Dolgushin and Osipova (1975) \\
\hline Kolka & 6 & 3 & 1 & Krenke and Rototayev (1973) \\
\hline \multicolumn{5}{|l|}{ Tien-shan } \\
\hline Mushketov & 21 & 70 & 2 & Dolgushin and Osipova (1975) \\
\hline Bezymyanny & 6 & 11 & 2 & Dolgushin and Osipova (1975) \\
\hline \multicolumn{5}{|l|}{ Karakoram } \\
\hline Kutiah & 12 & - & 1 & Desio (1954) \\
\hline Baltbare & 8 & - & 2 & Wang and others (1984) \\
\hline \multicolumn{5}{|l|}{ Andes } \\
\hline Grande del Junca & 10 & 9 & 1 & Espizua (1986) \\
\hline Grande del Nevado & 6 & 5 & 1 & Bruce and others (1987) \\
\hline
\end{tabular}


have minimum surge durations of $3-4$ years (Table 1 ), but in both cases the true duration of the active phase is likely to be somewhat longer, remaining unreported as a result of the lack of continuity in the observational record. This means that there is almost no overlap between the frequency distributions recording surge duration for Svalbard ice masses compared with those from other glacierized regions (Fig. $7 \mathrm{~d}-\mathrm{e}$ ). We acknowledge that surge-duration data are available for only a small sub-set of those ice masses known to surge (cf. Fig. 1), and for no high polar glaciers outside Svalbard, but a highly significant contrast in active-phase length has been demonstrated nonetheless.

This systematic difference in the length of the active phase of the surge cycle requires a physical explanation. Given that some combination of basal lubrication and high water pressures is suggested to be basic to fast motion in both "hard" and "soft" bed theories of surging (e.g. Clarke and others, 1984; Kamb and others, 1985; Kamb, 1987), the differences in surge duration we report must imply either some systematic difference in the rate of operation of basal processes or the operation of different processes beneath Svalbard ice masses and those from the areas listed in Table 2.

It should also be pointed out that a number of the areas listed in Table 2 are considerably warmer than the environment of Svalbard. Differences in thermal structure exist between, for example, the temperate glaciers of Iceland and sub-polar glaciers in Svalbard, where the thinner, outer parts of the ice mass are often cold-based while the accumulation area is typically temperate (e.g. Schytt, 1969; Nixon and others, 1985; Dowdeswell, 1986a). Glaciers of sub-polar thermal regime are also found in parts of Alaska and the Yukon, with Trapridge Glacier providing a well-known example (Clarke and others, 1984). Some theories of surge behaviour have suggested that thermal structure may be a primary control on surging (e.g. Schytt, 1969; Clarke, 1976). However, detailed observations at Trapridge Glacier in the Yukon, where the base is frozen below a distinctive bulge in the surface and wet above it, have shown that thermal evolution does not accompany progressive change in bulge morphology and mass build-up in a reservoir area (Clarke and others, 1984). We do not, therefore, imply that differences in thermal structure alone can account for the observed differences in the duration of surges on Svalbard glaciers as compared with those from other areas.

Much of the observational evidence required to test hypotheses concerning the long duration of the active phase on Svalbard surge-type glaciers has yet to be collected and few direct observations on basal conditions have been made beneath glaciers in the archipelago. A relative lack of water penetrating to the bed of sub-polar glaciers, due in part to refreezing on and within the ice, may be a possible explanation for relatively slow surge velocities if, using Kamb's (1987) model, multiple-conduit instability is not reached before the melt season ends. The pervasive presence of permafrost over the archipelago may also restrict the potential of unlithified sediments to deform rapidly, although it is not clear whether permafrost extends beneath the temperate accumulation areas of sub-polar glaciers.

\section{CONCLUSIONS}

The main conclusions of this paper are summarized as follows:

1. Many glaciers, both in Svalbard and in other glacierized regions, are known to surge (Fig. 1). However, the time series of observations required in order to assess the duration of fast motion is very restricted. Data on surge duration are available for less than 50 glaciers.

2. The duration of the active phase of the surge cycle is significantly longer for Svalbard glaciers than for surgetype glaciers in other areas. In Svalbard, the active phase may last from 3 to 10 years (Table 1; Fig. 6e). By contrast, a surge duration of 1-2 years is more typical for glaciers in northwest North America, Iceland and the Pamirs (Table 2; Fig. 6). The duration of glacier surges in high polar areas outside Svalbard is unknown, due to lack of data.

3 . Ice velocities during the protracted active phase on Svalbard glaciers are considerably lower than those for many surge-type glaciers in other regions for which data are available. Mass is thus transferred from a reservoir to a receiving area more slowly in Svalbard, but over a considerably longer period.

4. Velocities at the end of a surge appear to slow down over a protracted period (several years) for Svalbard ice masses, in contrast to the very rapid termination (a few days) of some surges of Alaskan glaciers.

5. The duration of the active phase is not dependent on parameters related to glacier size in the case of either Svalbard surge-type glaciers or those from other regions. 6 . The quiescent phase of the surge cycle is relatively long (50-500 years) for the few Svalbard ice masses for which evidence is available.

7. The finding that surge behaviour, in the form of activephase duration, shows systematic differences between different regions and their environments has important implications for understanding the processes responsible for glacier surges. Detailed field monitoring of changing basal conditions, and in particular hydrology and temperature, through the surge cycle is required for surge-type glaciers in Svalbard in order to explain the significantly longer length of the active phase and the slow rate of surge termination.

\section{ACKNOWLEDGEMENTS}

Many people have contributed to the reports on glacier surges we have used from Svalbard and elsewhere, and we are grateful to all of them. We thank in particular D.J. Drewry, T. Eiken, I. Frearson, O. Liestøl and N. W. Riley for providing observations on Svalbard glaciers. G. K. C. Clarke, K.A. Echelmeyer, W. D. Harrison and C.F. Raymond made helpful comments on the manuscript. G. S. Hamilton acknowledges support from a U.K. NERC research studentship.

\section{REFERENCES}

Bruce, R.H., G. A. Cabrera, J. C. Leiva and L. E. Lenzano. 1987. The 1985 surge and ice dam of Glaciar 
Grande del Nevado del Plomo, Argentina. 7. Glaciol., 33, 131-132.

Clarke, G. K. C. 1976. Thermal regulation of glacier surging. F. Glaciol., 16, 231-250.

Clarke, G. K. C. and S. G. Collins. 1984. The 1981-1982 surge of Hazard Glacier, Yukon Territory. Can. J. Earth Sci., 21, 297-304.

Clarke, G. K. C., S. G. Collins and D. E. Thompson. 1984. Flow, thermal structure, and subglacial conditions of a surge-type glacier. Can. J. Earth Sci., 21, 232-240.

Clarke, G. K.C., J.P. Schmok, C.S.L. Ommaney and S. G. Collins. 1986. Characteristics of surge-type glaciers. 7. Geophys. Res., 91(B7), 7165-7180.

Desinov, L. V. 1984. Podvizhka lednika Muzgazy [The surge of Muzgazy Glacier]. Mater. Glyatsiol. Issled. Khron. Obsuzhdeniya, 50, 145-146.

Desio, A. 1954. An exceptional glacier advance in the Karakoram-Ladakh region. F. Glaciol., 2, 383-385.

Dolgushin, L. D. and G. B. Osipova. 1975. Glacier surges and the problem of their forecasting. International Association of Hydrological Sciences Publication 104 (General Assembly of Moscow 1971 - Snow and Ice), 292-304.

Dowdeswell, J. A. 1986a. Drainage-basin characteristics of Nordaustlandet ice caps, Svalbard. 7. Glaciol., 32, 3138.

Dowdeswell, J. A. 1986b. Remote sensing of ice cap outlet glacier fluctuations on Nordaustlandet, Svalbard. Polar Res., 4, 25-32.

Dowdeswell, J. A. and R. L. Collin. 1990. Fast-flowing outlet glaciers on Svalbard ice caps. Geology, 18, 778781.

Dowdeswell, J. A. and D.J. Drewry. 1989. The dynamics of Austfonna, Nordaustlandet, Svalbard: surface velocities, mass balance, and subglacial melt water. Ann. Glaciol., 12, 37-45.

Drewry, D.J. and O. Liestøl. 1985. Glaciological investigations of surging ice caps in Nordaustlandet, Svalbard. Polar Rec., 22, 359-378.

Echelmeyer, K. and W. D. Harrison. 1989. Surge of West Fork Glacier, Alaska, U.S.A. Ann. Glaciol., 12, 212.

Echelmeyer, K., R. Butterfield and D. Cuillard. 1987. Some observations on a recent surge of Peters Glacier, Alaska, U.S.A. 7. Glaciol., 33, 341-348.

Espizua, L. E. 1986. Fluctuations of the Rio del Plomo glaciers. Geogr. Ann., 68A, 317-327.

Field, W. O. 1969. Current observations on three surges in Glacier Bay, Alaska, 1965-1968. Can. J. Earth Sci., 6, 831-839.

Fowler, A. C. 1987. A theory of glacier surges. 7. Geophys. Res., 92(B9), 9111-9120.

Glazyrin, G. Ye., G. M. Kamnyanskiy, A. B. Mazo, V.K. Nozdryukhin and A. N. Salamatin. 1987. Mekhanizm podvizhki lednika Abramova v 1972-1975 [Mechanism of the Abramova Glacier surge in 1972-1975]. Mater. Glyatsiol. Issled. Khron. Obsuzhdeniya, 60, 84-90.

Hagen, J. O. 1987. Glacier surge at Usherbreen, Svalbard. Polar Res., 5, 239-252.

Hagen, J.O. 1988. Glacier surges in Svalbard with examples from Usherbreen. Norsk Geogr. Tidsskr., 42, 202-213.

Hagen, J. O. and Liestøl, O. 1990. Long-term glacier mass-balance investigations in Svalbard, 1950-88. Ann. Glaciol., 14, 102-106.
Hallgrímsson, H. 1972. Hlaupid í Teigadalsjökli í Svarfadardal 1971 [The burst of Teigadalsjökull in Svarfadardalur 1971]. Jökull, 22, 79-82.

Hattersley-Smith, G. 1969. Recent observations on the surging Otto Glacier, Ellesmere Island. Can. J. Earth Sci., 6, 883-889.

Kamb, B. 1987. Glacier surge mechanism based on linked cavity configuration of the basal water conduit system. 7. Geophys. Res., 92(B9), 9083-9100.

Kamb, B. and 7 others. 1985. Glacier surge mechanism: 1982-1983 surge of Variegated Glacier, Alaska. Science, 227, 469-479.

Krenke, A. N. and K. P. Rototayev. 1973. A surge of the Kolka Glacier and its hydrometeorological consequences. International Association of Hydrological Sciences publication 107 (Symposium at Banff 1972 - Role of Snow and Ice in Hydrology), 1160-1171.

Krimmel, R. 1988. [Cover photograph.] Eos, 69, 1.

Lefauconnier, B. and Hagen, J.O. 1990. Glaciers and climate in Svalbard: statistical analysis and reconstruction of the Brøggerbreen mass balance for the last 77 years. Ann. Glaciol., 14, 148-152.

Liestøl, O. 1969. Glacier surges in west Spitsbergen. Can. 7. Earth Sci., 6, 895-897.

Liestøl, O. 1971. Glaciological work in 1970. Nor. Polarinst. Arbok, 1970, 240-251.

Liestøl, O. 1972. Glaciological work in 1971. Nor. Polarinst. Arbok, 1971, 67-75.

Liestøl, O. 1975. Glaciological work in 1974. Nor. Polarinst. Årbok, 1974, 183-194.

Liestøl, O. In press. Glaciers of Svalbard, Norway. U.S. Geol. Surv. Prof. Pap. 1386, chapter 5E.

Meier, M.F. and A.S. Post. 1969. What are glacier surges? Can. J. Earth Sci., 6, 807-817.

Moffit, H.F. 1942. Black Rapids Glacier, Alaska. U.S. Geol. Surv. Bull., 926-B, 146-160.

Muller, F. Was the Good Friday Glacier on Axel Heiberg Island surging? Can. J. Earth Sci., 6, 891-894.

Murav'yev, Ya. D., A. I. Farberov, O.S. Chubarova and Ye,S. Pribylov. 1987. Seysmovulkanicheskaya obstanovka na Ushkovskom vulkane i podvizhka lednika Bil'chenok v 1980-1983 [Seismovolcanic situation on the Ushakov volcano and the surge of Bil'chenok Glacier in 1980-1983]. Mat. Glyatsiol. Issled. Khron. Obsuzhdeniya, 60, 141-147.

Nixon, W.A. and 6 others. 1985. Applications and limitations of finite element modeling to glaciers: a case study. J. Geophys. Res., 90(B13), 11,303-11,311.

Post, A.S. 1960. The exceptional advances of the Muldrow, Black Rapids and Susitna Glaciers. F. Geophys. Res., 65, 3703-3712.

Post, A.S. 1965. Alaskan glaciers: recent observations in respect to the earthquake advance theory. Science, 148, 366-368.

Post, A.S. 1967. Effects of the March 1964 Alaska earthquake on glaciers. U.S. Geol. Surv. Prof. Pap. 544-D.

Post, A. 1969. Distribution of surging glaciers in western North America. 7. Glaciol., 8, 229-240.

Raymond, C. F. 1987. How do glaciers surge? A review. J. Geophys. Res., 92(B9), 9121-9134.

Raymond, C.F. and W.D. Harrison. 1986. Winter initiation of surges. Workshop on hydraulic effects at the glacier bed and related phenomena. Eidg. Tech. 
Hochschule, Zürich. Versuchsanst. Wasserbau, Hydrol. Glaciol. Mitt., 90, 85-86.

Rototayev, K.P. 1983. Dinamika lednika Byrs za posledniye 20 let [Dynamics of the Byrs Glacier for the last 20 years]. Mat. Glyatsiol. Issled. Khron. Obsuzhdeniya, 47, 147-156.

Schytt, V. 1969. Some comments on glacier surges in eastern Svalbard. Can. 7. Earth Sci., 6, 867-873.

Sigbjarnarsson, G. 1976. Hagafellsjökull eystri hlaupinn [The surge of Hagafellssjökull eystri]. Jökull, 26, 94-96.

Smith, N.D. 1990. The effects of glacial surging on sedimentation in a modern ice-contact lake, Alaska. Geol. Soc. Am. Bull., 102, 1393-1403.

Solheim, A. In press. The depositional environment of surging sub-polar tidewater glaciers: a case study of the morphology, sedimentation and sediment properties in a surge affected marine basin outside Nordaustlandet, northern Barents Sea. Nor. Polarinst. Skr.

Stanley, A. D. 1969. Observations of the surge of Steele Glacier, Yukon Territory, Canada. Can. F. Earth Sci., 6, 819-830.

Tarr, R. S. and L. Martin. 1914. Alaskan glacier studies of the National Geographic Society in the Yakutat Bay, Prince William Sound and lower Copper River regions. Washington, DC, National Geographic Society.
Theodórsson, T. 1980. Hagafellsjøklar taka á rás [The Hagafells glacier surges]. Fökull, 30, 75-77.

Thorarinsson, S. 1964. Sudden advance of Vatnajökull outlet glaciers 1930-1964. Jökull, 14, 76-89.

Thorarinsson, S. 1969. Glacier surges in Iceland, with special reference to the surges of Brúarjøkull. Can. $\mathcal{F}$. Earth Sci., 6, 875-882.

Uskov, Yu. S. and N. Dil'muradov. 1983. O podvizhkakh lednikov basseyna r. Sugran na Pamire [On the glacier surges in the Pamirs]. Mater. Glyatsiol. Issled. Khron. Obsuzhdeniya, 47, 142-146.

Wang Wenying, Huang Maohuan and Chen Jianming. 1984. A surging advance of Balt Bare Glacier, Karakoram mountains. In Miller, K. J., ed. The International Karakoram Project. Volume 1. Proceedings of the International Conference held at Quaid-i-Azam University, Islamabad, Pakistan. Cambridge, Cambridge University Press, 76-83.

Weidick, A. 1988. Surging glaciers in Greenland - a status. Gronl. Geol. Undersolgelse Rapp., 140, 106-110.

Williams, R.S., Jr. 1976. Vatnajökull icecap, Iceland. U.S. Geol. Surv. Prof. Pap. 929, 188-193.

The accuracy of references in the text and in this list is the responsibility of the authors, to whom queries should be addressed. 